\title{
ADDITIVE MANUFACTURING AS AN ENABLER FOR ENHANCED CONSUMER INVOLVEMENT\#
}

\author{
R.I. Campbell ${ }^{1 *}$, D.J . de Beer ${ }^{2}$, D.A. Mauchline ${ }^{3}$, L. Becker ${ }^{4}$, R. van der Grijp ${ }^{5}$, Y. Ariadi ${ }^{6}$ \\ \& M. A. Evans ${ }^{7}$
}

\author{
${ }^{1}$ Visiting Scientist at Vaal University of Technology \\ South Africa \\ r.i.campbell@lboro.ac.uk \\ ${ }^{2}$ North West University \\ South Africa \\ ${ }^{3,4,5} \mathrm{Vaal}$ University of Technology \\ South Africa \\ ${ }^{6,7}$ Loughborough University \\ United Kingdom
}

\begin{abstract}
This paper draws on previous work by the authors that aimed to use functional prototypes, produced using additive manufacturing (AM), as a means to draw customer input and preferences into the development of new products. This technique is referred to as Customer Interaction through Functional Prototypes (CIFP). The CIFP philosophy has been proven in both consumer and medical products. In recent years, the authors have developed further concepts of AM-enabled enhanced consumer involvement within their respective research teams. This paper discusses the extended use of CIFP to develop innovative new product concepts in the Vaal University of Technology, to support grantholders of the Industrial Development's Corporation (IDC) Support Programme for Industrial Innovation (SPII) and the Technology and Innovation Agency (TIA). The paper goes on to discuss a novel method of consumer interaction developed at Loughborough University, referred to as a Computer-aided Consumer Design (CaCODE). This technique allows nondesigners to take an existing product design (e.g., a pen) and modify its shape in real time, in order to create a customised version of the product that meets their needs. The modification is limited within pre-defined parameters to make sure that any final design is functional and can be produced using AM.
\end{abstract}

\section{OPSOMMING}

Hierdie artikel is geskoei op die gebruik van toevoegingsvervaardiging om kliënt insette en voorkeure in te sluit by die ontwikkeling van nuwe produkte. Die tegniek word die Kliënt Interaksie deur Funksionele Prototipes (CIFP) genoem. Die CIFP filosofie is al bewys in verbruikers- en mediese produkte. Verdere konsepte vir die gebruik van toevoegingsvervaardiging om kliënt betrokkenheid te bevorder is die die outeurs ontwikkel. Hierdie artikel bespreek die uitgebreide gebruik van CIFP om innoverende nuwe produkte te ontwikkel by die Vaal Universiteit van Tegnologie ter ondersteuning van navorsers wat steun van die Industriële Ontwikellings Korporasie (IDC) en die Tegnologie en Innovasie Agentskap (TIA) ontvang. Die artikel bespreek verder ' $n$ nuwe metode vir verbruiker interaksie soos ontwikkel by Loughborough Universiteit, bekend as Rekenaar gesteunde Verbruiker Ontwerp (CaCode). Dié tegniek laat ontwerp-leke toe om ' $n$ bestaande produk aan te pas om aan hulle vereistes te voldoen. Hierdie aanpassing is beperk binne voorafbepaalde parameters om te verseker dat die finale ontwerp funksioneel en vervaardigbaar is.

\footnotetext{
\# This article is an extended version of an article presented at the 2012 RAPDASA conference

* Corresponding author
} 


\section{$1 \quad$ INTRODUCTION}

In recent years, advances in additive manufacturing (AM) have enabled the development of more representative prototypes. This has come primarily through materials development, but also through improved accuracy and finish of AM models. This has meant that fullyfunctional prototypes can be produced that are very close to the end product, in terms of both material properties and visual appearance. Indeed, where the end product will be produced using $A M$, the final validation prototypes may actually be indistinguishable from the series production items. One consequence of this is that customers (whether clients or end users) can evaluate the prototypes as if they were using the end product, even in the final use environment. If this evaluation can be undertaken early in the product development process (essentially, as soon as a CAD model is available), then customer feedback can be used to help drive the remaining design iterations of the product. This has previously been termed 'Customer Involvement through Functional Prototypes' (CIFP), and has been demonstrated to be effective with consumer products [1], medical implants [2], and professional use products [3].

In these uses of CIFP, there was a clear distinction between the designer and the customer, with the designer leading the evolution of the product design. However, with the advent of mass customisation (MC) involving personalisation or individualisation, the terms 'user codesign' or 'customer integration' have become more familiar [4]. There is also an opinion that "with user-design systems, the professional designer is replaced by the user" [5]. Research at Vaal University of Technology has indicated that such wholesale replacement is not currently feasible, and that collaborative consumer design is required where part of the product design is done by the designer and the remainder by the consumer. This approach connects consumers' choices with the capabilities of the company, and extends the philosophy of concurrent engineering to sales, marketing, and end users. Tseng and Du [6] recommend this approach because it brings the voice of customers into design and manufacturing. With this in mind, the authors have developed further concepts of AMenabled enhanced consumer involvement within their respective research teams. This paper will discuss the extended use of CIFP to support entrepreneurs in developing innovative new product concepts. This paper will also discuss a novel method of consumer interaction that complements the use of CIFP, referred to as a Computer-aided Consumer Design (CaCODE).

\section{EXTENDING THE CIFP PHILOSOPHY}

The original CIFP philosophy was aimed at supporting designers within a conventional industrial environment. Typically, they would be working in a design consultancy or manufacturing company where they would be presented with a brief from an external or internal client. Fully-representative functional prototypes, produced using AM, would then be used to enable the client and/or end users of the product to provide feedback on aesthetics, ergonomics, or functionality. This can happen at several stages within the product development process, as shown in Figure 1.

This version of the CIFP methodology maintains a clear divide between the designer who develops the design solutions and produces the CAD models, and the customer who is brought in on several occasions to evaluate the prototypes. In more recent projects, this divide has started to erode, with customers performing some of the actions normally undertaken by the designer. With reference to Figure 1 , these customer design interventions are seen most often at the earlier stages of the process, but they can happen throughout. A typical example of early intervention is when an entrepreneur comes to the designer with a clear idea of market requirements, product design specification, and perhaps even some concept designs. For customer intervention in the latter stages of detail design (e.g., product manufacture and delivery), the term 'consumer designer' was coined to reflect the idea that the same person may be the designer, manufacturer, and user of 
the product. The application of CIFP within both of these scenarios is discussed in the following sections.

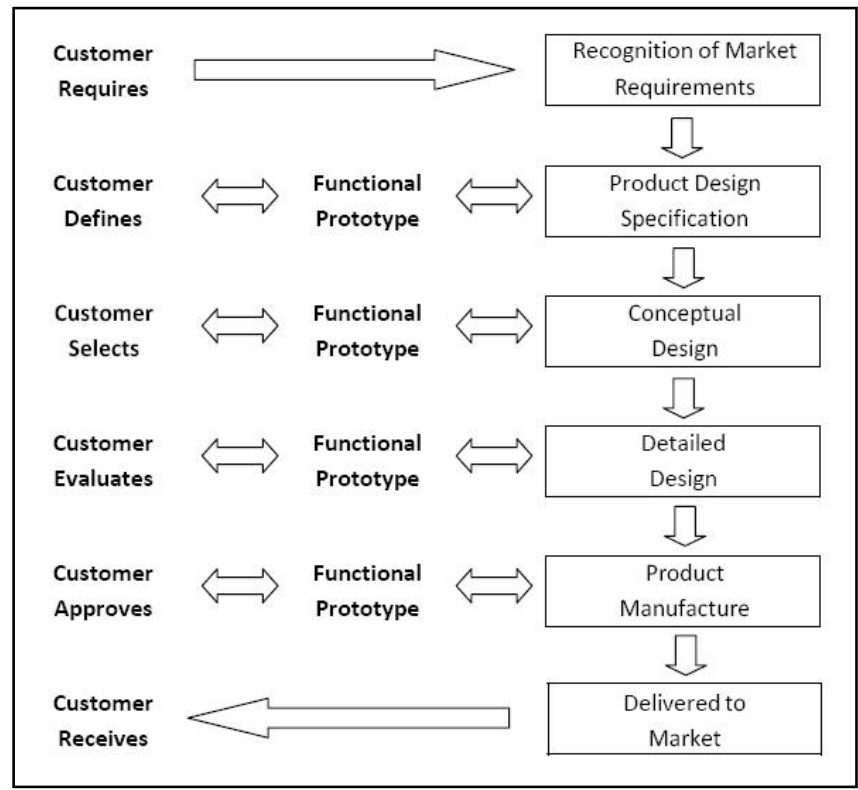

Figure 1: Use of CIFP within the product development process [1].

\section{USING CIFP TO SUPPORT ENTREPRENEURS}

Within the Vaal University of Technology (VUT), the Technology Transfer and Innovation Directorate has an ongoing remit to support grant-holders from the Industrial Development Corporation's (IDC) Support Programme for Industrial Innovation (SPII) and the Technology and Innovation Agency (TIA) in developing innovative new product ideas. Numerous SPII and TIA projects have been supported with design, prototyping, and tooling expertise, leading to the development of an extensive knowledge-base that has been used to support other types of projects. Many of these projects are initiated by entrepreneurs who come to the VUT with innovative ideas that need to be converted into viable product offerings. CIFP has played an integral role in supporting such entrepreneurs, as illustrated by the following project examples.

\subsection{Example 1: Motorcycle locking system}

The initial design idea was for a locking mechanism to secure a motorcycle to a trailer, for transportation behind a car. The client entrepreneur had already sketched a solution to the problem, and the original request to the VUT was for a functional prototype of this design to be produced using AM. The designers at VUT were sceptical about the design, but agreed to create a CAD model and build the prototype using AM parts and standard metal components. The prototype did not perform as the client had expected, and he agreed that a major re-design was needed. This re-design was undertaken by VUT designers, and once again a CAD model and prototype were built. The new lock design operated well, but the material properties of the lock cover were not sufficiently robust for a full 'impact test' to check the security of the design. Therefore, a silicon rubber moulding was taken from the prototype lock cover and used to create further copies in a polyurethane resin material (Figure 2) that had similar properties to the polymer that would be used for the final product. These met the performance requirements, and convinced both the client and the investors that production tools should be produced. The project showed that clients can lack professional design acumen, and that even a negative outcome from a CIFP evaluation can be valuable. 


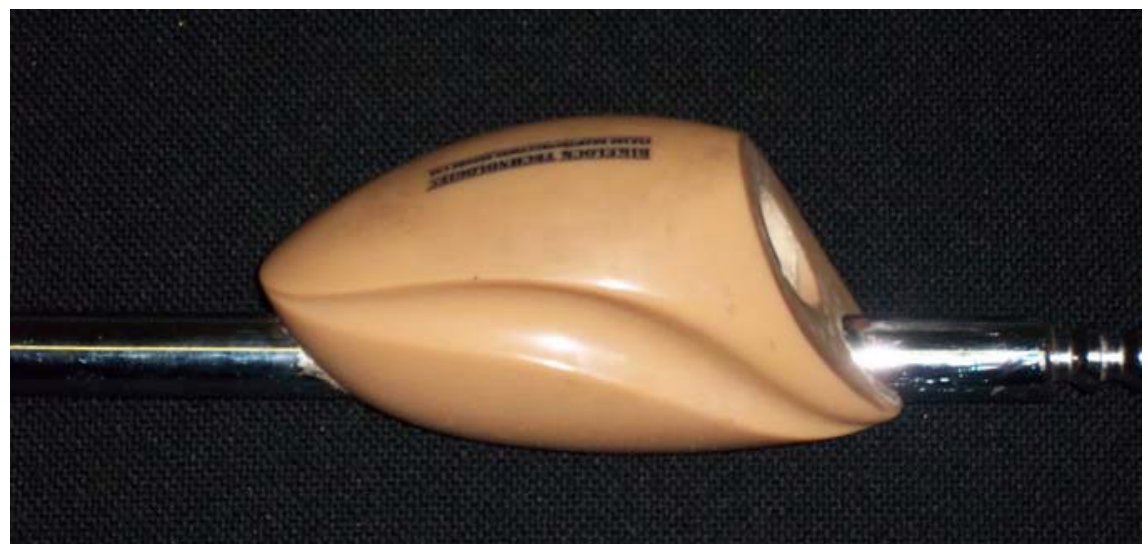

Figure 2: Lock cover from motorcycle locking system

\subsection{Example 2: Interlocking toy system}

The original idea from the client entrepreneur was to create an interlocking toy system that could make use of the internal cardboard tubes from kitchen- and toilet-rolls. The client entrepreneur had already created a 3-D design using the Sketch-up software. Research was undertaken to determine the internal diameters of cardboard tubes, and it was found that sizes varied across international markets. A standard South African size was chosen, and a refined design was generated using a 3-D CAD package. The VUT designer created a number of connector designs (straight, 45 degrees, 90 degrees, T-piece, and cross-piece) with tapered sections to fit into the cardboard tubes. A Dimension 3-D printer was used to create prototypes in ABS plastic, and silicon rubber moulds were used to produce prototypes for field-testing in several different colours of polyurethane resin (Figure 3 ). After the testing showed that the cardboard tubes held their shape very well, it was decided to re-design the connectors without the taper. New samples were built on the Dimension machine to confirm that this re-design worked. 'Soft' tooling was produced using CNC machining that incorporated the split planes and draft angles required for injection moulding. Around 300 parts were shot in four different colours so that a complete toy box could be shown to potential investors. Funding was received from investors, and production tooling was developed so that the product could be launched on the market. The ability to use fully-representative functional prototypes indicated that some design features that had seemed, intuitively, to be correct had actually turned out to be unnecessary.

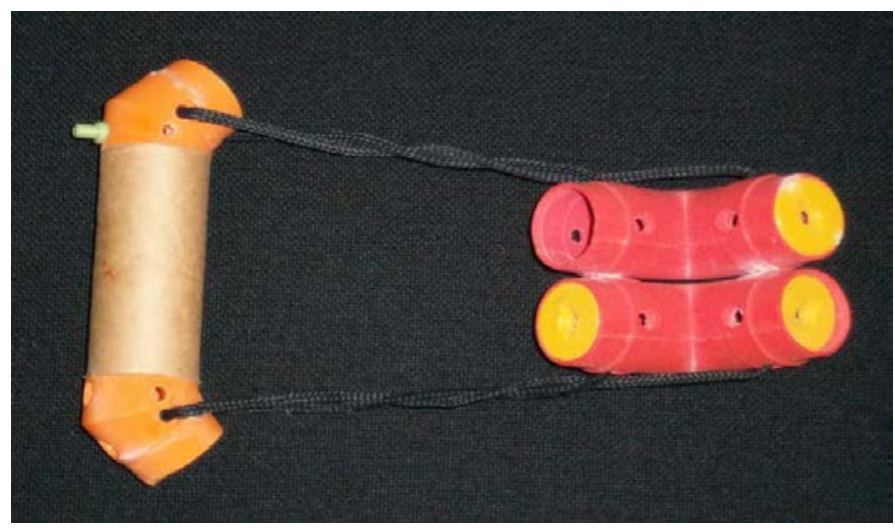

Figure 3: Connectors from interlocking toy system

\subsection{Example 3: Electronics enclosure for hand-held product}

The electronics for a hand-held market sampling device had already been developed, and now the client entrepreneur needed an enclosure to be designed. The client had a 2-D 
drawing of his preferred solution, which was cylindrical in form and incorporated a screen, LED lights, and push-button controls. An initial foam model was created to evaluate the ergonomics, and this revealed problems with reaching the push buttons. A re- design was undertaken and a fully-detailed CAD model developed. Prototype parts were built using laser sintering in polyamide, and all the electronics were assembled into them. The AM material chosen was very representative of injection-moulded parts in terms of wall thickness, the ability to use the final fasteners, and its robustness. The prototype was evaluated by both the client and the VUT designer, who suggested that an adhesive membrane pad should replace the push-buttons and LED lights, and that the screen should be covered in order to reduce the possibility of dirt ingress. Another iteration of the design was produced with the buttons on the membrane pad repositioned to allow for even easier reach. New laser-sintered prototypes were produced, finished, painted, and assembled with the electronics (Figure 4). The product is now undergoing field trials. The main findings from this project were that physical models are essential for ergonomic evaluation, and that professionally-finished AM models are sufficient for field testing, provided a suitable material is available.

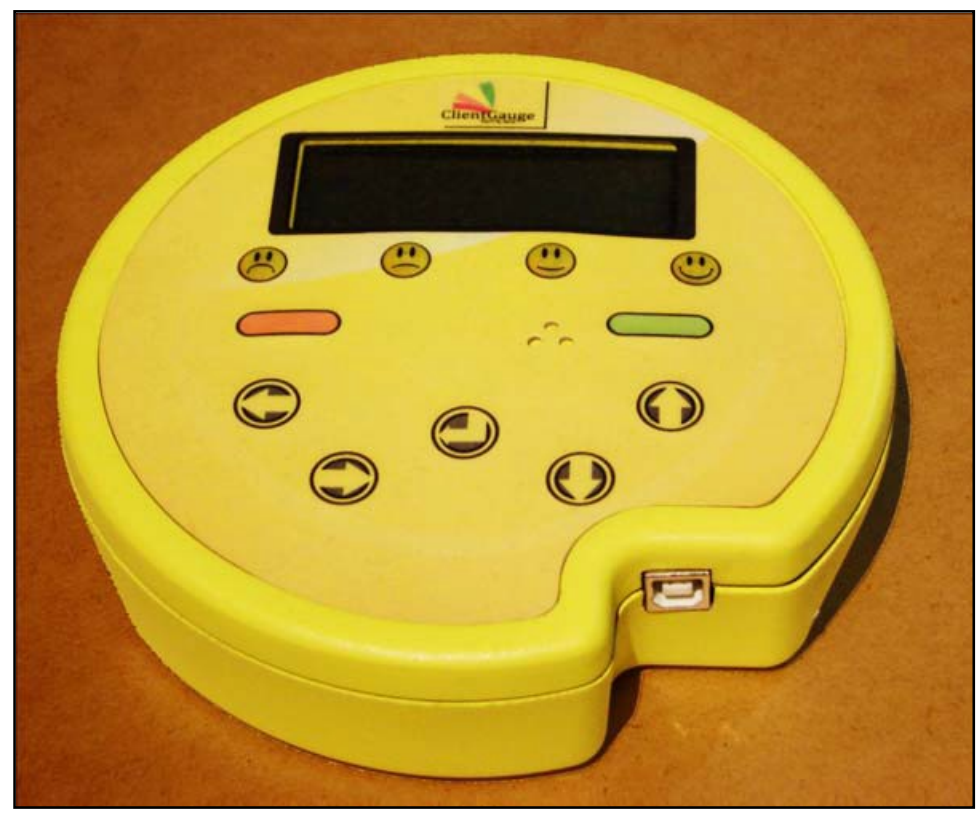

Figure 4: Fully assembled functional prototype

\section{COUPLING CIFP WITH CACODE}

Recent research at Loughborough University has identified that consumers wish to become more involved in the design and manufacture of their own personalised products, and that new digital technologies are needed to facilitate this [7]. Presenting such consumerdesigners with functional prototypes of their designs for evaluation (e.g., utilising CIFP) is desirable; but it requires the design to have been embodied in a fully-defined 3-D digital model. Since most consumers are incapable of using conventional CAD systems, the capture of their design intent is problematic, and the idea of starting from a 'blank sheet' is highly intimidating to many. To overcome these issues and facilitate prototype manufacture, the concept of CaCODE was developed. With CaCODE, the consumer is presented with one (or several) existing designs of a particular type of product, and given the ability to vary the design geometry through an easy-to-use 'click-and-drag' interface. The concept is similar to that employed by Digital Forming [8] and Nervous System [9]. To date, CaCODE systems have been developed for two simpler product applications (beaker design and pen design), 
and specified for two more complex products (wrist splint design and mobile phone design). The beaker design and pen design systems are discussed below.

\subsection{CaCODE for beaker design}

Assuming that the beaker shape will be rotationally-symmetrical, the only items needed for definition of a full 3-D model are a base diameter, a 2-D spline curve to define the profile, and the material thickness. All of these are standard functions within most CAD systems, so, in theory, any CAD system could be selected as the platform to develop CaCODE. However, one system in particular (Rhino with the Grasshopper extension) offered the ability to create a user-friendly, customised interface without the need for API programming. Therefore, a Grasshopper application was developed that first presents the user with a shaded image of a 'neutral' beaker design, and then allows them to modify it by clicking and dragging control points to re-define its profile curve and base diameter (Figure 5). When the user has completed the design, it can be exported as an STL file for manufacture as a functional prototype. If the consumer had access to their own AM system, this could happen within hours. A more likely scenario, however, is that they would submit the data via an on-line interface to a bureau who would manufacture the beaker and post it to them. At this stage, any deficiency in the aesthetics, ergonomics, or functionality of the beaker could be used by the consumer to drive an improved design of the beaker.

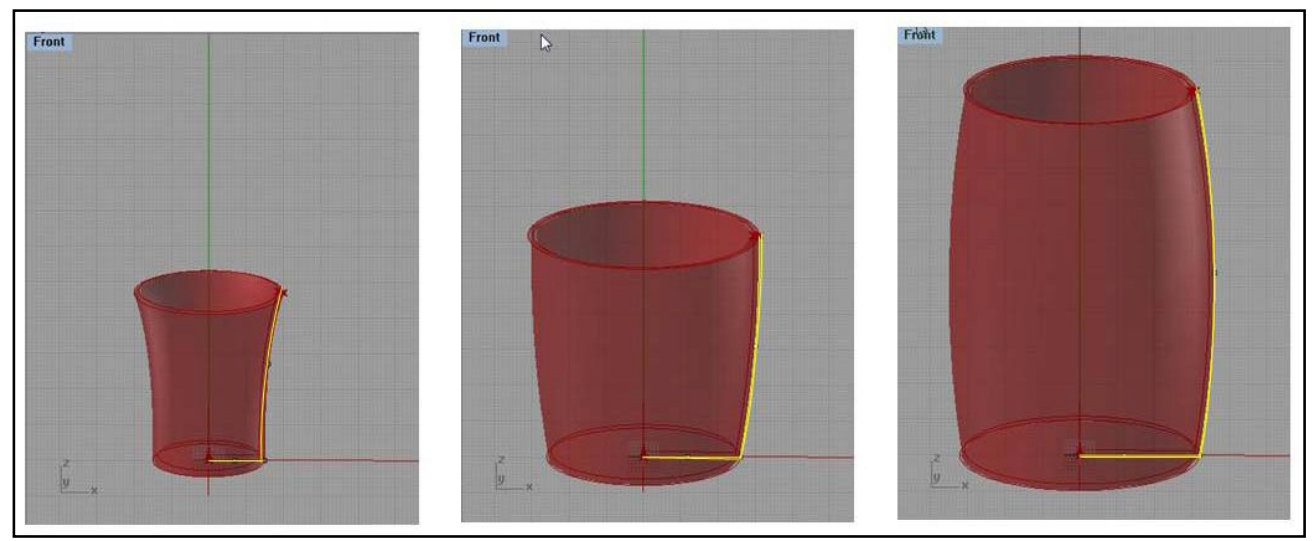

Figure 5: CaCODE interface for beaker design

\subsection{CaCODE for pen design}

The second application for CaCODE was an asymmetrical pen. Rhino with Grasshopper was used here too. This time, however, the shape of the product was determined by several dimensional parameters that were modified by the user, who used click-and-drag slider bars (Figure 6). As with the previous example, any input from the user resulted in an immediate re-shaping of the product on-screen. Since the pen had to fit comfortably within the user's hand and accommodate a standard-sized internal cartridge, upper and lower constraint values were placed on all of the dimensions. This established an important principle in that the user did not have unlimited control of the shape, thus ensuring that all the possible solutions would be feasible, at least from a geometrical point of view. As CaCODE is applied to more and more complex products, the ability to limit user freedom in the interest of safety, ergonomics, functionality, or some other critical aspect of design will become increasingly important. It is neither reasonable nor desirable to expect consumers to be able to design every aspect of a product. 


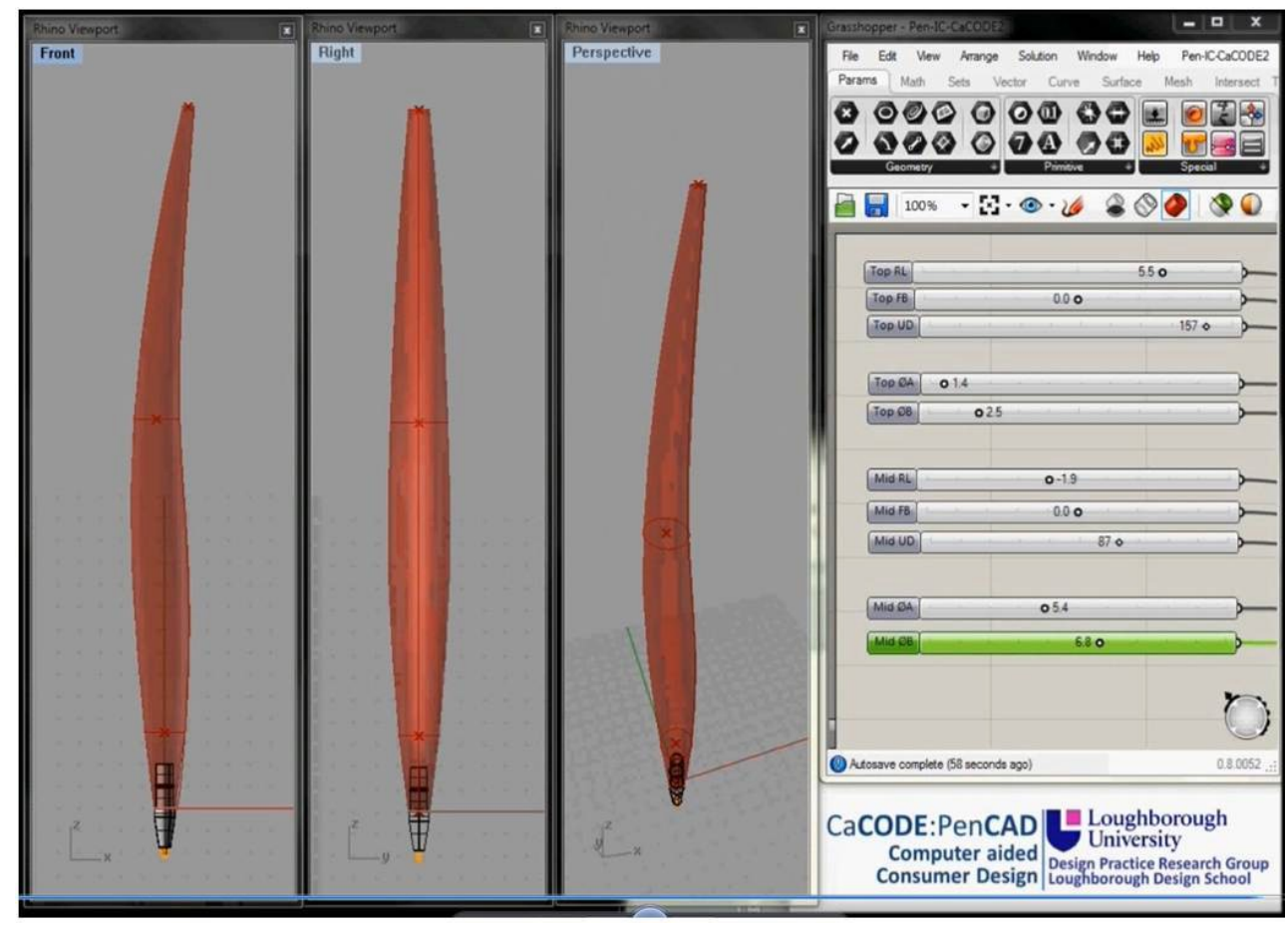

Figure 6: CaCODE interface for pen design

\section{CONCLUSIONS AND FUTURE DIRECTIONS}

The ability to convert the initial designs of entrepreneurs into feasible products, and to give consumers the ability to generate their own designs directly, brings customer interaction to a new level. In combination with AM and new design tools such as CaCODE, CIFP (Customer Involvement through Functional Prototypes) could be re-defined to mean 'Customer-initiated Feasible Products'. The role of the customer has been elevated from being a passive recipient of 'expert' designs to the active originator of design innovation. The knowledge input of the expert designer is still crucial, and can be incorporated either through conventional design practice (as in the three project cases at the VUT) or through building design rules into CaCODE software. In this way, the final design of the product becomes a true collaboration between customer and designer. An ideal environment for such collaboration to happen is the Idea to Product (I2P $\mathrm{P}^{\mathrm{TM}}$ ) Laboratory currently operating at the VUT. The $12 \mathrm{P}^{\mathrm{TM}}$ facility provides access to and training for entry-level CAD and entrylevel AM for school learners, students, and individuals wanting to create first samples of their innovative ideas. Plans are afoot to roll-out the $12 \mathrm{P}^{\mathrm{TM}}$ approach in South Africa and internationally.

In the future, it is anticipated that more consumers will want to have a direct influence on the shape of the products they buy. This means that software solutions will be needed that go beyond product configurators, which mainly facilitate the choosing of colours, patterns, textures, and other options from pre-defined lists. One hypothesis is that designers will need to create deliberately 'unfinished' designs that leave room for consumers to add their own personalised input [10]. The extent to which consumers will be able - or will want - to create such personalised products is largely unknown. It is already happening in a few specialised areas, but the feasibility of its application to more commonly-used products such as mobile phones has not been determined. Future research should concentrate on assessing the usability and desirability of the CIFP and CaCODE method among entrepreneurs and the general public. 


\section{REFERENCES}

[1] Campbell, R.I., de Beer, D.J., Barnard, L.J., Booysen, G.J., Truscott, M., Cain, R., Burton, M.J., Gyi, D.E., Hague, R.J.M. 2007. Design Evolution through Customer Interaction with Functional Prototypes, J ournal of Engineering Design, 18(6), pp. 617-635.

[2] Truscott, M., de Beer, D., Vicatos, G., Hosking, K., Barnard, L., Booysen, G., Campbell, R.I. 2007. Using RP to promote collaborative design of customised medical implants, Rapid Prototyping J ournal, 13(2), pp. 107-114.

[3] de Beer, D.J., Campbell, R.I., Truscott, M., Barnard, L.J ., Booysen, G.J . 2009. Client-centred Design Evolution via Functional Prototyping, International J ournal of Product Development, 8(1), pp. 22-41.

[4] Franke, N. \& Piller, F.T. 2003. Key research issues in user interaction with user toolkits in a mass customization system. International J ournal of Technology Management, 26(5-6), pp. 578599.

[5] Randall, T., Terwiesch, C. \& Ulrich, K.T. 2007. User design of customized products. Marketing Science, 26(2), pp. 268-280.

[6] Tseng, M.M. \& Du, X. 1998. Design by customers for mass customization products. CIRP Annals Manufacturing Technology, 47(1), pp. 103-106.

[7] Sinclair, M., Campbell, R.I., Ariadi, Y. and Evans, M.A. 2011. AM-enabled Consumer Design, In de Beer, D.J., du Preez, W. (ed) 12th Annual RAPDASA Conference, Proceedings of 12th Annual RAPDASA Conference, VanderbijIpark, South Africa.

[8] Digital Forming. 2012. Retrieved from: http:// www.digitalforming.com/. Accessed in J uly 2012.

[9] Nervous System. 2012. Retrieved from: http://n-e-r-v-o-u-s.com/cellCycle/. Accessed in July 2012.

[10] Sinclair, M. 2012. The specification of a consumer design toolkit to support personalised production via additive manufacturing. PhD thesis, Design School, Loughborough University. 